University of Nebraska - Lincoln

DigitalCommons@University of Nebraska - Lincoln

Agronomy \& Horticulture -- Faculty Publications

Agronomy and Horticulture Department

2-1-2001

\title{
Predicting Forage Quality in Switchgrass and Big Bluestem
}

\author{
Rob Mitchell \\ Texas Tech University, rob.mitchell@ars.usda.gov \\ John Fritz \\ Kansas State University \\ Ken Moore \\ lowa State University, kjmoore@iastate.edu \\ Lowell E. Moser \\ University of Nebraska-Lincoln, Imoser1@unl.edu \\ Ken Vogel \\ USDA-ARS, kvogel1@unl.edu
}

See next page for additional authors

Follow this and additional works at: https://digitalcommons.unl.edu/agronomyfacpub

Part of the Plant Sciences Commons

Mitchell, Rob; Fritz, John; Moore, Ken; Moser, Lowell E.; Vogel, Ken; Redfearn, Daren D.; and Wester, David, "Predicting Forage Quality in Switchgrass and Big Bluestem" (2001). Agronomy \& Horticulture -- Faculty Publications. 37.

https://digitalcommons.unl.edu/agronomyfacpub/37

This Article is brought to you for free and open access by the Agronomy and Horticulture Department at DigitalCommons@University of Nebraska - Lincoln. It has been accepted for inclusion in Agronomy \& Horticulture -Faculty Publications by an authorized administrator of DigitalCommons@University of Nebraska - Lincoln. 


\section{Authors}

Rob Mitchell, John Fritz, Ken Moore, Lowell E. Moser, Ken Vogel, Daren D. Redfearn, and David Wester 


\title{
Predicting Forage Quality in Switchgrass and Big Bluestem
}

\author{
Rob Mitchell,* John Fritz, Ken Moore, Lowell Moser, Ken Vogel, Daren Redfearn, and David Wester
}

\begin{abstract}
Predicting forage quality would help producers schedule hay harvesting to obtain desired hay quality. Our objective was to determine if growing degree day (GDD), day of the year (DOY), mean stage count (MSC), and mean stage weight (MSW) could be used to predict in vitro digestible dry matter (IVDDM), crude protein (CP), and neutral-detergent fiber (NDF) of 'Trailblazer' switchgrass (Panicum virgatum.) and 'Pawnee' big bluestem (Andropogon gerardii Vitman) grown in Nebraska and Kansas. This field study was conducted from 1990 to 1993 at Mead, NE on Typic Argiudoll soils and from 1992 to 1993 at Manhattan, KS on Aquic Argiudoll soils. Plants were sampled at 1-wk intervals in 1990 and 1991 and at 2-wk intervals in 1992 and 1993. They were morphologically classified as MSC and MSW and analyzed for IVDDM, CP, and NDF. Switchgrass IVDDM and CP were best predicted by GDD models, which accounted for 86 and $91 \%$ of the variation, respectively, whereas NDF was best predicted by MSC and MSW. Big bluestem IVDDM was best predicted by MSW and CP was best predicted by GDD, which both accounted for $90 \%$ of the variation. Mean stage weight accounted for $74 \%$ of the variability in big bluestem NDF. The DOY model adequately predicted forage quality due primarily to the determinate growth habit of these species. Morphological development accurately predicted forage quality in many instances. Although no universal parameter adequately predicted concentrations of IVDDM, CP, and NDF, it was possible to accurately predict quality with readily available environmental data and measures of plant maturity.
\end{abstract}

$\mathrm{T}$ HE FORAGE QUALITY OF WARM-SEASON GRASSES is initially moderate to high but declines rapidly with maturity (Perry and Baltensperger, 1979; Griffin and Jung, 1983; Mitchell et al., 1994a). Switchgrass and big bluestem are perennial, warm-season grasses that are native to the central Great Plains. These grasses are photoperiod sensitive (Benedict, 1941) and determinate in growth habit. Switchgrass has an erect growth form with leaves evenly distributed throughout the canopy, whereas big bluestem maintains numerous basal leaves (Moser and Vogel, 1995). Switchgrass and big bluestem have become increasingly important as pasture grasses in the central and eastern USA because they are productive during the hot summer months when cool-season grasses are relatively unproductive (Moser and Vogel, 1995). Changes in the concentrations of IVDDM, CP, and NDF throughout the growing season have been well

R. Mitchell and D. Wester, Dep. of Range, Wildlife, and Fisheries Management, Texas Tech Univ., Lubbock, TX 79409; J. Fritz, Dep. of Agron., Kansas State Univ., Manhattan, KS 66506; K. Moore, Dep. of Agron., Iowa State Univ., Ames, IA 50011; L. Moser, Dep. of Agron., Univ. of Nebraska, Lincoln, NE 68583; K. Vogel, USDAARS, Dep. of Agron., Univ. of Nebraska, Lincoln, NE 68583; and D. Redfearn, Louisiana State Univ. Agric. Cent., Southeast Res. Stn., Franklinton, LA 70438. Joint contribution of the Univ. of Nebraska, Lincoln Agric. Res. Division, Journal Ser. no. 12039; Kansas State Univ., Contribution no. 96-117-J; and Texas Tech Univ., T-9-791. Received 25 Feb. 2000.*Corresponding author (rob.mitchell@ ttu.edu).

Published in Agron. J. 93:118-124 (2001). documented for switchgrass and big bluestem (Perry and Baltensperger, 1979; George and Hall, 1983; Griffin and Jung, 1983; Mitchell et al., 1994a). However, most of the studies that have evaluated changes in forage quality have been comparisons of switchgrass and big bluestem on specific DOYs or at generalized vegetative or reproductive stages. No studies have been conducted where changes in the forage quality of switchgrass and big bluestem have been documented with quantified changes in morphological development.

The morphological development of perennial grasses is an important consideration when making forage management decisions (Kalu and Fick, 1983; Moore and Moser, 1995). Plant maturity is the primary factor affecting the morphological development and forage quality within a species (Kalu and Fick, 1983; Nelson and Moser, 1994). A system for quantifying the morphological development of perennial grasses based on the MSC and MSW was developed by Moore et al. (1991). This system was used to quantify the morphological development of switchgrass and big bluestem in Nebraska and Kansas (Mitchell et al., 1997) and differentiate the developmental stages in weeping lovegrass [Eragrostis curvula (Schrad.) Nees] in Texas (McFarland and Mitchell, 2000). A knowledge of the forage quality relationships with morphological development may aid in making planning decisions such as when to harvest hay or graze pastures (Hill et al., 1995).

Forage quality should be matched to animal requirements. Systems for quantifying the relationships between the morphological stage of development and forage quality have been successfully developed for alfalfa (Medicago sativa L.) (Kalu and Fick, 1981; Kalu and Fick, 1983). However, in perennial, cool-season grasses such as tall fescue (Festuca arundinacea Schreb.), the morphological development was a poor predictor of the forage quality (Hill et al., 1995). Predicting forage quality changes based on accumulated GDD, DOY, or developmental morphology would provide valuable information for estimating animal performance or predicting potential forage quality losses associated with delaying harvest (Hill et al., 1995). The objective of this study was to determine if the GDD, DOY, MSC, and MSW could be used to predict the forage quality for switchgrass and big bluestem grown in several environments in the central Great Plains.

\section{MATERIALS AND METHODS \\ Prediction Equation Development}

Pure stands of Trailblazer switchgrass and Pawnee big bluestem were seeded in 1986 as a randomized complete block

Abbreviations: CP, crude protein; DOY, day of the year; GDD, growing degree days; IVDDM, in vitro digestible dry matter; MSC, mean stage count; MSW, mean stage weight; NDF, neutral-detergent fiber; RMSE, root mean square error. 
split-plot with six replicates on a Sharpsburg silty clay loam soil (fine, montmorillonitic, mesic, Typic Argiudoll) at the University of Nebraska Agricultural Research and Develop-

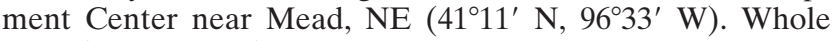
plots $(1.2$ by $4.6 \mathrm{~m})$ were species and subplots were harvests. Standing dead material was mowed to a $2-\mathrm{cm}$ stubble height, and residue was removed before the initiation of spring growth each year. Nitrogen was applied in late May 1990 and 1991 at $110 \mathrm{~kg} \mathrm{~N} \mathrm{ha}{ }^{-1}$. Plots were hand-weeded throughout the growing season.

The tillers used for morphological classification were handclipped at ground level from $0.09-\mathrm{m}^{2}$ quadrats that were randomly located within each whole plot. The tillers were transported to the laboratory and morphologically classified using the system described by Moore et al. (1991). Quantitative indices of developmental morphology were assigned at the conclusion of each growing season based on the total number of events in the vegetative and elongation stages. The MSC and MSW were determined for each species at each harvest date to quantify the developmental morphology of the tiller populations. The accumulated GDD were calculated as the sum of the difference between the mean daily temperature and a base temperature of $10^{\circ} \mathrm{C}$ after 1 January.

The first growth of switchgrass and big bluestem were sampled at approximately 7-d intervals beginning 6 June and concluding 6 Sept. 1990 and beginning 22 May and concluding 3 Sept. 1991. Whole-plant samples used for the IVDDM, CP, and NDF were clipped to ground level from $0.25-\mathrm{m}^{2}$ quadrats, sorted to remove dead tissue, oven-dried to a constant weight at $55^{\circ} \mathrm{C}$, and ground to pass a $1-\mathrm{mm}$ screen. Concentrations of the IVDDM were determined using the inoculation and direct acidification procedure described by Marten and Barnes (1980). Rumen fluid was collected from two cannulated steers (Bos taurus); one was maintained on an alfalfa hay diet and the other on a corn (Zea mays L.) cob diet. The rumen fluid from each cannulated steer was mixed in a 1:1 ratio (vol./vol.), and the rumen fluid mixture was combined with a buffer containing $1 \mathrm{~g} \mathrm{~L}^{-1}$ urea $\left[\left(\mathrm{NH}_{2}\right)_{2} \mathrm{CO}\right]$ in a 1:1 ratio (vol./vol.). Crude protein was quantified using the Kjeldahl procedure for $\mathrm{N}$ determination $\left(\mathrm{g} \mathrm{kg}^{-1} \mathrm{CP}=\mathrm{g} \mathrm{kg}^{-1} \mathrm{~N} \times 6.25\right.$; AOAC, 1990). The NDF concentration was determined according to Goering and Van Soest (1970).

The accumulated GDD, DOY, MSC, and MSW were included as independent variables. Linear, quadratic, and cubic effects were evaluated, with replicate means of the indices of forage quality as dependent variables of the pooled data set for each species from 1990 and 1991 using the PROC REG procedure of SAS (SAS Inst., 1985). Data from 1990 and 1991 were pooled so that the calibration data set represented a broad range of environmental conditions. Higher-order equations were selected based on the significance $(P=0.10)$ of additional coefficients.

\section{Validation of Prediction Equations}

The validation study was conducted in 1992 and 1993 at the University of Nebraska Agricultural Research and Development Center near Mead, NE and the Kansas State University Agronomy North Farm near Manhattan, KS (39 $11^{\prime} \mathrm{N}$, $\left.96^{\circ} 33^{\prime} \mathrm{W}\right)$. Validation plots for Trailblazer switchgrass and Pawnee big bluestem were established in 1991 on a Sharpsburg silty clay loam soil in Nebraska and on a Wymore silty clay loam soil (fine, montmorillonitic, mesic, Aquic Argiudoll) in Kansas as randomized complete blocks arranged as split-plots with three replicates. Whole plots $(5$ by $10 \mathrm{~m}$ ) were species and were divided into two equal portions ( 5 by $5 \mathrm{~m}$ ). In 1992, one-half of each whole plot was randomly selected and divided into six subplots ( 1.7 by $2.5 \mathrm{~m}$ ) that were randomly assigned for each harvest date. The same field sampling procedure used for the collection of prediction samples was used for the validation samples. Vegetation on the plots to be harvested in 1993 remained undisturbed throughout the 1992 growing season. In 1993, the previously nonharvested portion of each whole plot was divided into six subplots and randomly assigned for each harvest date. Standing dead material was mowed to a $2-\mathrm{cm}$ stubble height and residue was removed before the initiation of spring growth. Nitrogen was applied in late May 1992 and 1993 at $110 \mathrm{~kg} \mathrm{~N} \mathrm{ha}^{-1}$. In Nebraska, switchgrass and big bluestem were harvested on 20 May, 3 and 17 June, 2 and 14 July, and 12 Aug. 1992 and 1993. In Kansas, both species were harvested on 19 May, 4 and 19 June, 1 and 14 July, and 10 Aug. 1992. The harvest dates in 1993 were 10 and 25 June, 12 and 22 July, and 6 and 18 August. Plants were hand-clipped and morphologically classified as MSC and MSW, and forage quality analyses were conducted in the same manner as the calibration study.

The concentrations of IVDDM, CP, and NDF in validation samples were predicted using the regression equations for accumulated GDD, DOY, MSC, and MSW developed from the calibration study. The predicted forage quality values $(Y)$ were regressed against the actual laboratory forage quality values $(X)$ of the replicate means from the validation sample set for each species across environments using the PROC REG procedure of SAS (SAS Inst., 1985). The goodness of fit for each model was determined by evaluating the coefficient of determination, root mean square error (RMSE), slope, and intercept of the regression line describing the relationship between the predicted and actual forage quality values. The intercepts were evaluated to determine if they differed from $0(P=0.05)$ and if the slopes differed from $1(P=0.05)$.

\section{RESULTS AND DISCUSSION Environmental Conditions}

The accumulated GDD appeared greater in 1991 than in 1990 (Fig. 1). The accumulated GDD in Nebraska appeared similar throughout the 1992 and 1993 growing seasons; similar GDD accumulations were observed in Kansas during the 1992 and 1993 growing seasons (Fig. 1). However, the accumulated GDD at the conclusion of sampling in Kansas were at least 15\% greater in 1992 and 1993 than those accumulated in Nebraska by the same date. Additionally, accumulated GDD for the calibration experiments were approximately $10 \%$ higher than those accumulated during the validation experiments.

The long-term average annual precipitation at Mead, $\mathrm{NE}$ is $680 \mathrm{~mm}$, with $500 \mathrm{~mm}$ occurring between 1 April and 1 October. The annual precipitation was near or exceeded the long-term average at Mead, NE in 1990, 1991, 1992, and 1993, totaling 687, 780, 658, and 859 $\mathrm{mm}$, respectively. The long-term average annual precipitation at Manhattan, $\mathrm{KS}$ is $860 \mathrm{~mm}$, with $600 \mathrm{~mm}$ occurring between 1 April and 1 October. The annual precipitation in Manhattan, KS during 1992 and 1993 was above the long-term average, with 1053 and 1264 $\mathrm{mm}$ occurring each year, respectively.

\section{Fit of Calibration Equations}

The regression equations for predicting the switchgrass IVDDM and CP from the GDD, DOY, MSC, and 

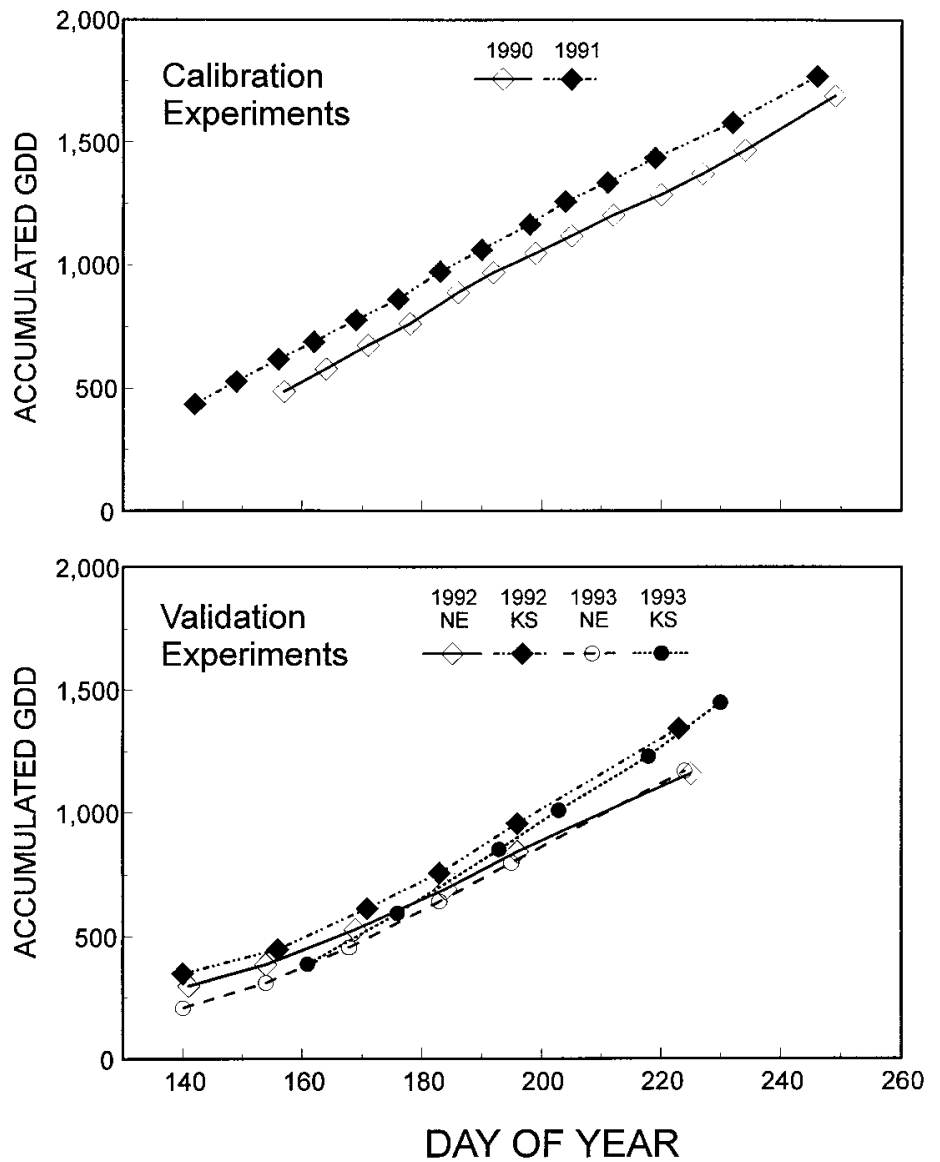

Fig. 1. Accumulated growing degree days (GDD) for calibration and validation studies near Mead, NE in 1990, 1991, 1992, and 1993 and Manhattan, KS in 1992 and 1993.

MSW had coefficients of determination $\geq 0.92$ and low RMSE statistics (Table 1). However, the regression equations for predicting the switchgrass NDF from the GDD, DOY, MSC, and MSW had coefficients of determination $\leq 0.70$. The regression equations for predicting the big bluestem IVDDM and CP from the GDD, DOY, MSC, and MSW had coefficients of determination $\geq 0.83$ and low RMSE statistics. The regression equations for predicting the big bluestem NDF from the GDD, DOY, MSC, and MSW had coefficients of determination $\leq 0.75$ and were generally higher than for switchgrass (Table 1). The calibration equations with the highest coefficient of determination and lowest RMSE for the IVDDM, $\mathrm{CP}$, and NDF based on the GDD, DOY, MSC, or MSW were plotted for both species (Fig. 2, 3, and 4). In many cases, the linear models accounted for less variability than the quadratic or cubic models. However, where the linear models provide reasonable results, data from the linear models are discussed to provide a simpler interpretation of the data and may have additional utility for predicting quality parameters.

The switchgrass IVDDM calibration data was best predicted by a quadratic DOY model, which accounted for $96 \%$ of the variability in the IVDDM (Fig. 2), whereas a linear DOY model accounted for $91 \%$ of the variability in the IVDDM. The big bluestem IVDDM calibration data was best predicted by a linear accumulated GDD model ( $r^{2}=0.97$; Fig. 2$)$, but a linear DOY model gave nearly as good of fit $\left(r^{2}=0.94\right)$. The wholeplant IVDDM ranged from 295 to $746 \mathrm{~g} \mathrm{~kg}^{-1}$ for switchgrass and 275 to $695 \mathrm{~g} \mathrm{~kg}^{-1}$ for big bluestem. As the growing season progressed, the whole-plant IVDDM declined by an average of $4 \mathrm{~g} \mathrm{~kg}^{-1} \mathrm{~d}^{-1}$ for both switchgrass and big bluestem. The decline in switchgrass and big bluestem IVDDM as the growing season progressed was consistent with previous research in the central Great Plains (Perry and Baltensperger, 1979; Mitchell et al., 1994a). The concentrations of IVDDM in switchgrass were generally greater than those observed for big bluestem on common days of the year, which was similar to previous research (George and Hall, 1983).

The switchgrass $\mathrm{CP}$ calibration data was best predicted by a quadratic MSC model, which accounted for $96 \%$ of the variability in the CP (Fig. 3 ), whereas a linear MSC model accounted for only $80 \%$ of the variability in the $\mathrm{CP}$. The switchgrass $\mathrm{CP}$ was predicted nearly as well by GDD, DOY, and MSW models (Table 1); therefore, a DOY equation would be the easiest to use. The big bluestem CP calibration data were better predicted by a quadratic model based on accumulated GDD than any other model (Table 1). The quadratic accumulated GDD model accounted for $96 \%$ of the variability in the CP (Fig. 3), whereas a linear GDD model accounted for only $84 \%$ of the variability in the CP. The wholeplant CP ranged from 34 to $182 \mathrm{~g} \mathrm{~kg}^{-1}$ for switchgrass 
Table 1. Calibration equations, coefficients of determination, and root mean square errors (RMSE) for predicting forage quality with day of the year (DOY), accumulated growing degree day (GDD), mean stage count (MSC), and mean stage weight (MSW) for switchgrass and big bluestem grown near Mead, NE in 1990 and 1991.

\begin{tabular}{|c|c|c|c|}
\hline Quality parameter & Calibration equations & Coefficient of determination & RMSE \\
\hline \multicolumn{4}{|l|}{$\mathrm{g} \mathrm{kg}^{-1}$} \\
\hline \multicolumn{4}{|c|}{$\underline{\text { Switchgrass }}$} \\
\hline \multirow[t]{4}{*}{ IVDDM $\dagger$} & $1059.99-0.81($ GDD $\left.)+0.0002\left(G^{2}\right)^{2}\right)$ & 0.95 & 28 \\
\hline & $2398.03-15.68(\mathrm{DOY})+\mathbf{0 . 0 3}\left(\mathrm{DOY}^{2}\right)$ & 0.96 & 27 \\
\hline & $\mathbf{1 3 8 7 . 8 4}-\mathbf{5 0 7 . 2 6}(\mathrm{MSC})+\mathbf{6 0 . 5}\left(\mathrm{MSC}^{2}\right)$ & 0.92 & 38 \\
\hline & 1439.61-518.17(MSW) + 61.22(MSW $\left.{ }^{2}\right)$ & 0.92 & 36 \\
\hline \multirow[t]{4}{*}{$\mathbf{C P}$} & $263.85-0.30(G D D)+0.0001\left(G^{2} D^{2}\right)$ & 0.95 & 9 \\
\hline & $879.38-7.29(\mathrm{DOY})+0.016\left(\mathrm{DOY}^{2}\right)$ & 0.95 & 9 \\
\hline & 421.33 - 221.04(MSC) $+31.84\left(\mathrm{MSC}^{2}\right)$ & 0.96 & 8 \\
\hline & $414.05-202.05($ MSW $)+27.01\left(\right.$ MSW $\left.^{2}\right)$ & 0.94 & 9 \\
\hline \multirow[t]{4}{*}{ NDF } & $540.42+0.37($ GDD $)-0.0001\left(G^{2} D^{2}\right)$ & 0.49 & 31 \\
\hline & $-3253.96+56.51(\mathrm{DOY})-0.26\left(\mathrm{DOY}^{2}\right)+0.0004\left(\mathrm{DOY}^{3}\right)$ & 0.70 & 25 \\
\hline & $389.36+246.60($ MSC $)-40.03\left(\right.$ MSC $\left.^{2}\right)$ & 0.45 & 33 \\
\hline & $405.36+218.76(\mathrm{MSW})-32.75\left(\mathrm{MSW}^{2}\right)$ & 0.43 & 33 \\
\hline \multicolumn{4}{|c|}{$\underline{\text { Big bluestem }}$} \\
\hline \multirow[t]{4}{*}{ IVDDM } & $835.02-0.33(G D D)$ & 0.97 & 23 \\
\hline & $1281.32-4.05(\mathrm{DOY})$ & 0.94 & 32 \\
\hline & $1381.66-677.42\left(\right.$ MSC) $+105.41\left(\right.$ MSC $\left.^{2}\right)$ & 0.92 & 38 \\
\hline & 1126.22 - 397.86(MSW) $+46.53\left(\mathrm{MSW}^{2}\right)$ & 0.93 & 35 \\
\hline \multirow[t]{4}{*}{$\mathbf{C P}$} & $277.32-0.31(G D D)+0.0001\left(G_{D D}^{2}\right)$ & 0.96 & 9 \\
\hline & $868.99-7.05(\mathrm{DOY})+\mathbf{0 . 0 1 5}\left(\mathrm{DOY}^{2}\right)$ & 0.92 & 12 \\
\hline & $439.85-304.80\left(\right.$ MSC) $+\mathbf{5 6 . 0 8}\left(\right.$ MSC $\left.^{2}\right)$ & 0.83 & 17 \\
\hline & $352.81-200.94($ MSW $)+31.22\left(\right.$ MSW $\left.^{2}\right)$ & 0.87 & 15 \\
\hline \multirow[t]{4}{*}{ NDF } & $602.96+0.19($ GDD $)-0.00006\left(G^{2} D^{2}\right)$ & 0.70 & 20 \\
\hline & $537.20+0.84(\mathrm{DOY})$ & 0.52 & 25 \\
\hline & $504.13+179.54\left(\right.$ MSC) $-28.72\left(\right.$ MSC $\left.^{2}\right)$ & 0.75 & 18 \\
\hline & $269.2+509.5(\mathrm{MSW})-180.4\left(\mathrm{MSW}^{2}\right)+21.7\left(\mathrm{MSW}^{3}\right)$ & 0.75 & 18 \\
\hline
\end{tabular}

$\dagger$ IVDDM, in vitro digestible dry matter.

$+\mathrm{CP}$, crude protein.

$\S$ NDF, neutral-detergent fiber.

and 28 to $179 \mathrm{~g} \mathrm{~kg}^{-1}$ for big bluestem and declined as the growing season progressed. Previous research has reported similar declines in the switchgrass and big bluestem CP with the progression of the growing season (Griffin and Jung, 1983). The switchgrass CP has been reported to be lower than big bluestem on common DOYs (Griffin and Jung, 1983). However, when the switchgrass and big bluestem $\mathrm{CP}$ were compared across all environments in the current study, no differences $(P>0.10)$ were found, which indicates the need to further evaluate quality differences in switchgrass and big bluestem.

The switchgrass NDF calibration data was best predicted by a cubic DOY model, which accounted for $70 \%$ of the variability in the NDF (Fig. 4), whereas a quadratic DOY model accounted for $63 \%$ of the variability in the NDF. Throughout the growing season, the switchgrass whole-plant NDF ranged from 637 to $819 \mathrm{~g}$ $\mathrm{kg}^{-1}$. The big bluestem NDF calibration data was best predicted by quadratic MSC and cubic MSW models, both which accounted for $75 \%$ of the variability in the NDF (Fig. 4). A linear MSC model accounted for $68 \%$ of the variability in the NDF, and a quadratic MSW model accounted for $70 \%$ of the variability in the NDF. Throughout the growing season, the big bluestem whole-plant NDF ranged from 646 to $791 \mathrm{~g} \mathrm{~kg}^{-1}$.

\section{Predicted vs. Actual Equations}

A perfect agreement between predicted and actual forage quality data would require an intercept of 0.0 (no bias), a linear coefficient equal to 1.0, an $r^{2}$ equal to 1.0, and an RMSE equal to 0.0 (Hill et al., 1995).
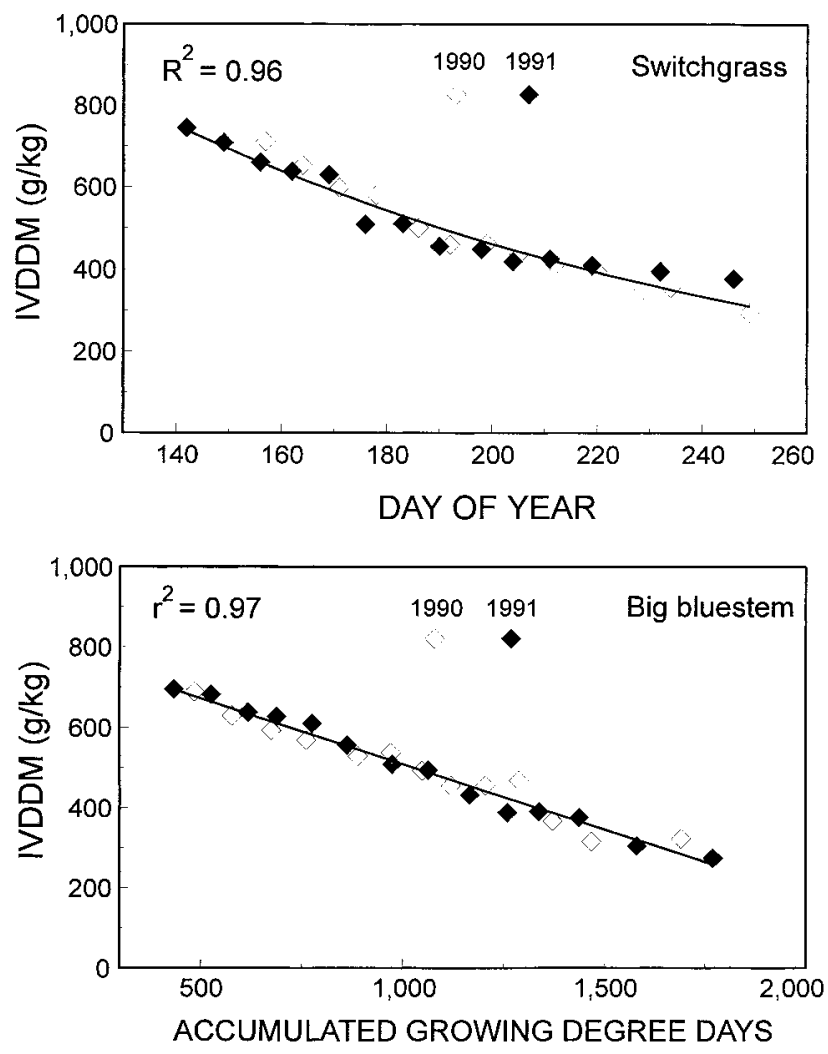

Fig. 2. Calibration parameters that best predicted in vitro digestible dry matter (IVDDM) for switchgrass and big bluestem grown near Mead, NE in 1990 and 1991. Equation of the line is given in Table 1. 

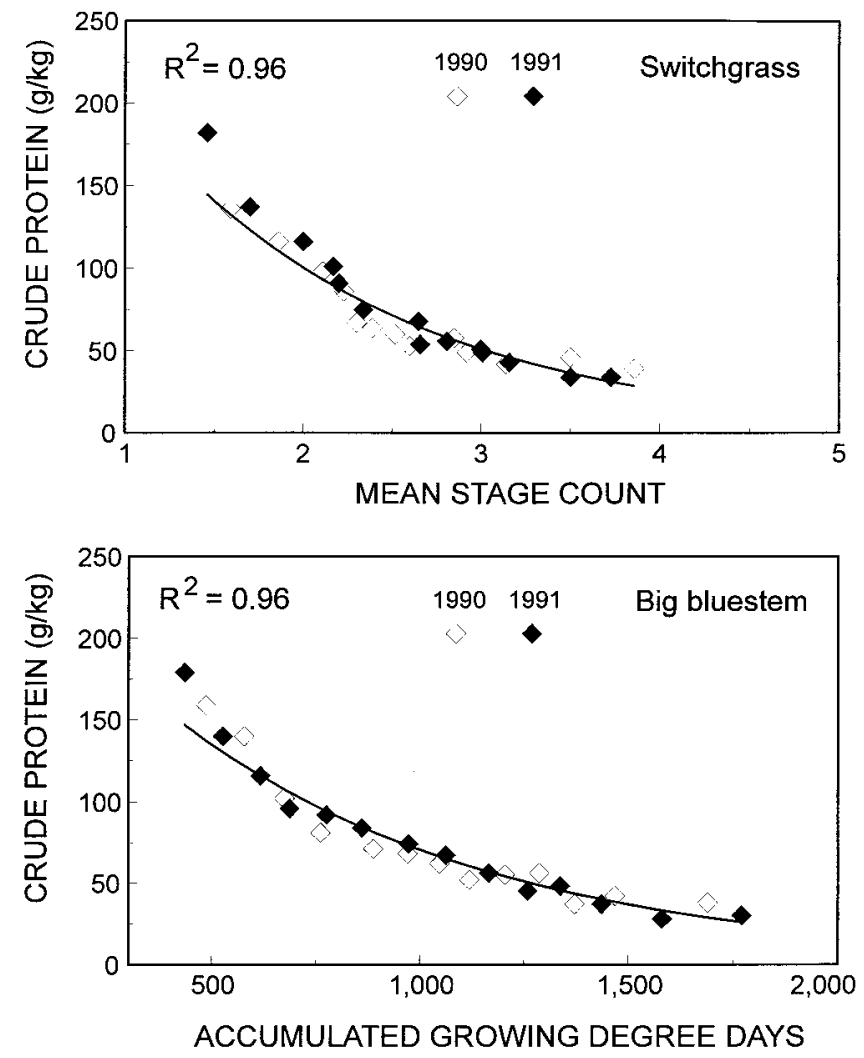

Fig. 3. Calibration parameters that best predicted crude protein (CP) concentration for switchgrass and big bluestem grown near Mead, $\mathrm{NE}$ in 1990 and 1991. Equation of the line is given in Table 1.

The best prediction equations for switchgrass and big bluestem were determined by evaluating the $r^{2}$, RMSE, intercept, and linear coefficient of each validation equation (Tables 2 and 3 ). Of the calibration equations identified as having the best fits for the IVDDM, CP, and NDF of switchgrass and big bluestem (Table 1), only the GDD model for the big bluestem CP was also the best equation for comparing predicted and actual values (Table 3).

The switchgrass IVDDM and CP were best predicted by the GDD regression equations across environments, accounting for at least $86 \%$ of the variation in forage quality (Table 2). However, the DOY, MSC, and MSW equations all had high coefficients of determination $\left(r^{2} \geq 0.76\right)$ and reasonable RMSEs $\left(\leq 74 \mathrm{~g} \mathrm{~kg}^{-1}\right)$ for predicting the IVDDM. The GDD equation accounted for $86 \%$ of the variation associated with the IVDDM in Nebraska and Kansas and had an RMSE of $67 \mathrm{~g} \mathrm{~kg}^{-1}$. The switchgrass CP was also well predicted by the DOY, MSC, and MSW equations, which had high coefficients of determination $\left(\mathrm{r}^{2} \geq 0.82\right)$ and low RMSEs $(\leq 20 \mathrm{~g}$ $\mathrm{kg}^{-1}$ ), indicating that switchgrass $\mathrm{CP}$ follows very predictable patterns throughout the growing season. From a managerial aspect, the DOY may be the best general predictor of the IVDDM and $\mathrm{CP}$, whereas predictions based on GDD may be more accurate within a large geographic region. The switchgrass NDF was best predicted by MSC and MSW regression equations, which were similar across environments. The MSC and MSW equations accounted for 82 and $83 \%$, respectively, of
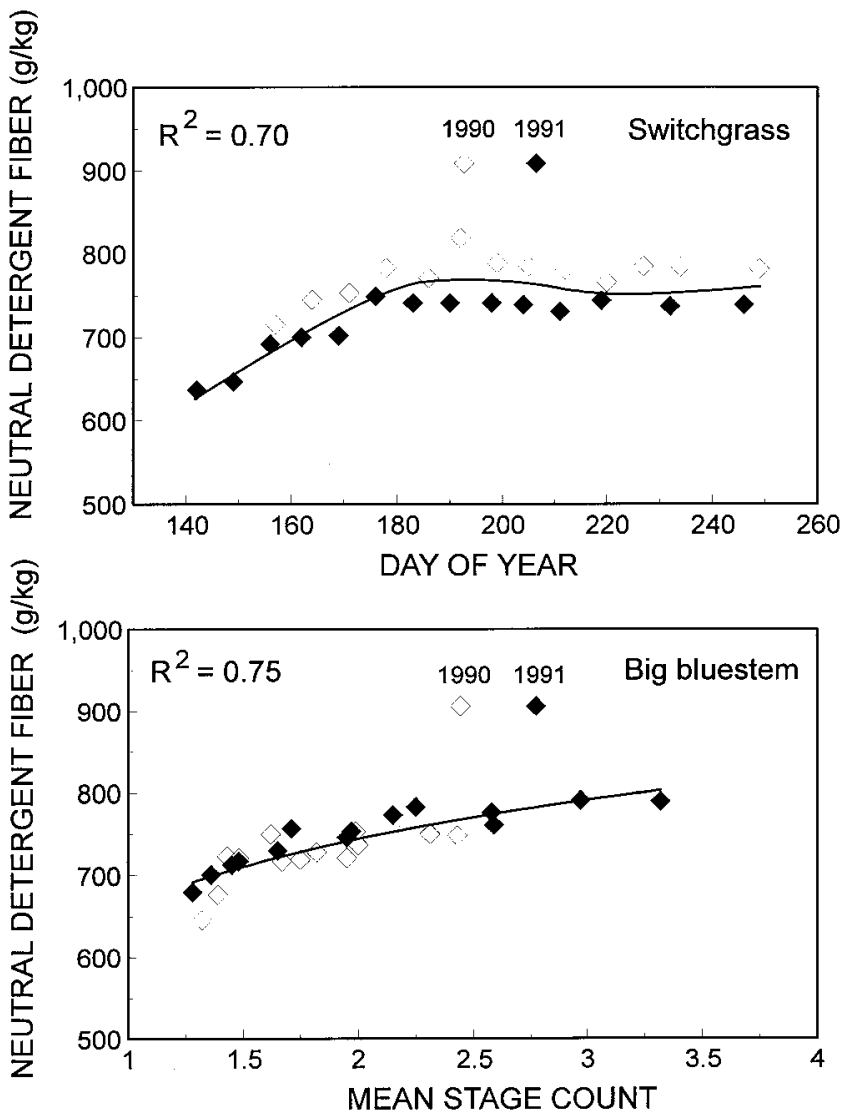

Fig. 4. Calibration parameters that best predicted neutral-detergen fiber (NDF) concentration for switchgrass and big bluestem grown near Mead, NE in 1990 and 1991. Equation of the line is given in Table 1.

the variation associated with the NDF in Nebraska and Kansas and had low RMSE statistics of $18 \mathrm{~g} \mathrm{~kg}^{-1}$. The GDD and DOY equations had lower coefficients of determination $\left(r^{2}=0.73\right.$ and 0.71$)$ and higher RMSEs (40 and $36 \mathrm{~g} \mathrm{~kg}^{-1}$ ). The GDD and DOY have been reported to be better predictors of the forage fiber components than the morphological development in coolseason grasses (Hill et al., 1995). The biological premise is that increasing temperature generally increases the cell wall component of grasses (Van Soest, 1982). Consequently, the incorporation of temperature in the GDD calculation helps explain cell wall deposition. However, based on the coefficient of determination, the switchgrass NDF did not respond to the GDD in as predictable a manner as previous observations with cool-season grasses but was best predicted by the morphological development.

The big bluestem IVDDM was best predicted by the MSW regression equation across environments $\left(r^{2}=\right.$ 0.90; Table 3). However, the GDD, DOY, and MSC equations all had high coefficients of determination $\left(r^{2} \geq 0.86\right)$ and low RMSEs $\left(44 \mathrm{~g} \mathrm{~kg}^{-1}\right)$. The big bluestem $\mathrm{CP}$ was best predicted by the GDD regression equation across environments (Table 3 ). The coefficient of determination for the GDD equation was considerably higher than for all other equations. The GDD equation accounted for $90 \%$ of the variation associated with $\mathrm{CP}$ 
Table 2. Validation of the switchgrass calibration equations for forage quality parameters $\left(\mathrm{g} \mathrm{kg}^{-1}\right)$ based on accumulated growing degree day (GDD), day of the year (DOY), mean stage count (MSC), and mean stage weight (MSW) models for switchgrass grown near Mead, NE and Manhattan, KS in 1992 and $1993(n=24)$. Parenthetic values following intercepts and linear coefficients are the $P$ values for the intercept $=0$ test and slope $=1$ test, respectively.

\begin{tabular}{|c|c|c|c|c|c|}
\hline Quality parameter & Model type & Intercept & Linear coefficient & $r^{2} \dagger$ & RMSE $\ddagger$ \\
\hline \multirow[t]{4}{*}{ IVDDM§ } & GDD & $-18.1(0.75)$ & $1.14(0.18)$ & 0.86 & 67 \\
\hline & DOY & $120.1(0.04)$ & $0.80(0.05)$ & 0.76 & 66 \\
\hline & MSC & $35.6(0.51)$ & $0.97(0.74)$ & 0.83 & 65 \\
\hline & MSW & $42.1(0.49)$ & $0.96(0.70)$ & 0.78 & 74 \\
\hline \multirow[t]{4}{*}{ CPII } & GDD & $-27.0(0.01)$ & $1.32(0.01)$ & 0.91 & 15 \\
\hline & DOY & $-11.1(0.33)$ & $1.01(0.92)$ & 0.82 & 18 \\
\hline & MSC & $-36.4(0.01)$ & $1.26(0.02)$ & 0.87 & 18 \\
\hline & MSW & $-35.2(0.01)$ & $1.24(0.05)$ & 0.84 & 20 \\
\hline \multirow[t]{4}{*}{ NDF\# } & GDD & $-96.3(0.39)$ & $1.12(0.42)$ & 0.73 & 40 \\
\hline & DOY & $92.5(0.35)$ & $0.65(0.66)$ & 0.71 & 36 \\
\hline & MSC & $231.4(0.01)$ & $0.66(0.01)$ & 0.82 & 18 \\
\hline & MSW & $227.6(0.01)$ & $0.67(0.01)$ & 0.83 & 18 \\
\hline
\end{tabular}

$\dagger$ Coefficient of simple determination.

+ Root mean square error.

§ IVDDM, in vitro digestible dry matter.

II $\mathrm{CP}$, crude protein.

\# NDF, neutral-detergent fiber.

and had an RMSE of $18 \mathrm{~g} \mathrm{~kg}^{-1}$. The DOY regression equation also had a high coefficient of determination and low RMSE, but it did not predict $\mathrm{CP}$ as well as the GDD equation. For the NDF, the cubic MSW equation accounted for $74 \%$ of the variation. The GDD, DOY, and MSC equations had lower coefficients of determination and RMSEs and linear coefficients that were different than 1.0.

The GDD or DOY regression equations were generally better predictors of the forage quality of switchgrass and big bluestem than the MSC or MSW regression equations. The MSW was a better predictor of the forage quality of big bluestem than the MSC (Table 3). The MSW is based on the weight of individual tillers, whereas the MSC is a weighted average of all of the tillers present (Kalu and Fick, 1981). Because mature big bluestem tillers weighed more than juvenile tillers (data not shown), the MSW incorporated the dilution of forage quality by the mature tillers, and therefore was a better predictor of the big bluestem IVDDM, CP, and NDF than the MSC (Kalu and Fick, 1981).

No single variable was able to consistently predict the IVDDM, CP, and NDF for switchgrass (Table 2) or big bluestem (Table 3). However, the accumulated GDD or DOY often provided reasonable forage quality predictions. The DOY adequately predicted the forage quality parameters for both species in the validation study due primarily to the photoperiod sensitivity of both species and the general predictability of weather patterns (i.e., rainfall and temperature). From a forage quality perspective, these data are contrary to the general recommendation to manage these species based on the status of the plant instead of the calendar date (Mitchell et al., 1994b). It is unlikely that forage quality predictions based on DOY equations developed in the central Great Plains would be appropriate in the northern and southern extremes of the species range. Variations in the photoperiod and adapted cultivars would make forage quality estimations difficult on the species level. However, GDD models are more likely than DOY models to be applicable for adapted cultivars over large geographic regions. Incorporating additional environmental variables such as hours of above-horizon sunlight, radiant energy, wind speed, or deviation between pan evaporation and precipitation to GDD may increase the precision of forage quality estimates across numer-

Table 3. Validation of the big bluestem calibration equations for forage quality parameters $\left(\mathrm{g} \mathrm{kg}^{-1}\right)$ based on accumulated growing degree day (GDD), day of the year (DOY), mean stage count (MSC), and mean stage weight (MSW) models for big bluestem grown near Mead, NE and Manhattan, KS in 1992 and $1993(n=24)$. Parenthetic values following intercepts and linear coefficients are the $P$ values for the intercept $=0$ and slope $=1$ test, respectively.

\begin{tabular}{|c|c|c|c|c|c|}
\hline Quality parameter & Model type & Intercept & Linear coefficient & $r^{2} \dagger$ & RMSE $\div$ \\
\hline \multirow[t]{4}{*}{ IVDDM§ } & GDD & $88.5(0.06)$ & $0.92(0.29)$ & 0.87 & 44 \\
\hline & DOY & $41.8(0.36)$ & $0.90(0.24)$ & 0.86 & 44 \\
\hline & MSC & $55.4(0.22)$ & $0.90(0.22)$ & 0.86 & 44 \\
\hline & MSW & $66.6(0.08)$ & $0.88(0.07)$ & 0.90 & 35 \\
\hline \multirow{4}{*}{ CPII } & GDD & $-39.5(0.01)$ & $1.60(0.01)$ & 0.90 & 18 \\
\hline & DOY & $-26.6(0.05)$ & $1.23(0.08)$ & 0.81 & 20 \\
\hline & MSC & $8.3(0.59)$ & $0.89(0.46)$ & 0.62 & 23 \\
\hline & MSW & $5.3(0.71)$ & $0.91(0.52)$ & 0.67 & 21 \\
\hline \multirow[t]{4}{*}{ NDF\# } & GDD & $197.4(0.01)$ & $0.69(0.01)$ & 0.70 & 19 \\
\hline & DOY & $350.7(0.01)$ & $0.46(0.01)$ & 0.65 & 14 \\
\hline & MSC & $313.0(0.01)$ & $0.56(0.01)$ & 0.63 & 18 \\
\hline & MSW & $298.4(0.01)$ & $0.58(0.01)$ & 0.74 & 15 \\
\hline
\end{tabular}

$\dagger$ Coefficient of simple determination.

$\$$ Root mean square error.

§ IVDDM, in vitro digestible dry matter.

II CP, crude protein.

\# NDF, neutral-detergent fiber. 
ous environments (Onstad and Fick, 1983; Hill et al., 1995).

The morphological development provided reasonable predictions for several forage quality parameters in switchgrass and big bluestem. The developmental morphology of switchgrass and big bluestem occurs in a very predictable manner, and it increased linearly with the DOY across six environments in Nebraska and Kansas (Mitchell et al., 1997). Although predictable, the morphological development of a plant, as quantified by the MSC and MSW, is a biological phenomenon and responds to macroenvironmental and microenvironmental factors. It is not surprising that the mean of a response variable (plant development) does not consistently and accurately predict another response variable (forage quality). The MSC and MSW integrate the tiller development over a range of stages in tiller populations. Future research needs to evaluate if separating and analyzing tillers by developmental stage improves the predictability of forage quality parameters. It is likely that the tiller age within a developmental stage impacts the forage quality in a similar manner to tiller maturity. Although morphological development accurately predicted the forage quality in many instances, the greatest utility to the scientific community in collecting standardized morphological development (MSC or MSW) data may be in communicating population growth stage data that is precise and numerically quantified, rather than presenting DOY or qualitative maturity estimates. Even though no universal parameter was able to adequately predicted the concentrations of IVDDM, CP, and NDF in switchgrass and big bluestem, it was possible to accurately predict quality with readily available environmental data and measures of plant maturity.

\section{REFERENCES}

AOAC. 1990. Official methods of analysis. 15th ed. AOAC, Arlington, VA.

Benedict, H.M. 1941. Effect of day length and temperature on the flowering and growth of four species of grasses. J. Agric. Res. 61:661-672.

George, J.R., and K.E. Hall. 1983. Herbage quality of three warmseason grasses with nitrogen fertilization. Iowa State J. Res. 58: 247-259.
Goering, H.K., and P.J. Van Soest. 1970. Forage fiber analyses (apparatus, reagents, procedures, and some applications). Agric. Handb. 379. USDA-ARS, Washington, DC

Griffin, J.L., and G.A. Jung. 1983. Leaf and stem quality of big bluestem and switchgrass. Agron. J. 75:723-726.

Hill, N.S., M.L. Cabrera, and C.S. Agee. 1995. Morphological and climatological predictors of forage quality in tall fescue. Crop Sci. 35:541-549.

Kalu, B.A., and G.W. Fick. 1981. Quantifying morphological development for studies of herbage quality. Crop Sci. 21:267-271.

Kalu, B.A., and G.W. Fick. 1983. Morphological stage of development as a predictor of alfalfa herbage quality. Crop Sci. 23:1167-1172.

Marten, G.C., and R.F. Barnes. 1980. Prediction of energy digestibility of forages with in vitro rumen fermentation and fungal enzymes systems. p. 61-71. In W.J. Pigden et al. (ed.) Standardization of analytical methodology for feeds. Proc. Int. Workshop, Ottawa, Canada. 12-14 Mar. 1979. Int. Res. and Dev. Cent. Rep. 134e. Unipub, New York.

McFarland, J.B., and R.B. Mitchell. 2000. Fire effects on weeping lovegrass tiller density and demographics. Agron. J. 92:42-47.

Mitchell, R.B., R.A. Masters, S.S. Waller, K.J. Moore, and L.E. Moser. 1994a. Big bluestem production and forage quality response to burning date and fertilizer in tallgrass prairie. J. Prod. Agric. 7:355-359.

Mitchell, R.B., K.J. Moore, L.E. Moser, J.O. Fritz, and D.D. Redfearn. 1997. Predicting developmental morphology in switchgrass and big bluestem. Agron. J. 89:827-832.

Mitchell, R.B., L.E. Moser, B.E. Anderson, and S.S. Waller. 1994b. Switchgrass and big bluestem for grazing and hay. Univ. of Nebraska Coop. Ext. Serv. NebGuide G94-1198-A.

Moore, K.J., and L.E. Moser. 1995. Quantifying developmental morphology of perennial grasses. Crop Sci. 35:37-43.

Moore, K.J., L.E. Moser, K.P. Vogel, S.S. Waller, B.E. Johnson, and J.F. Pedersen. 1991. Describing and quantifying growth stages of perennial forage grasses. Agron. J. 83:1073-1077.

Moser, L.E., and K.P. Vogel. 1995. Switchgrass, big bluestem, and indiangrass. p. 409-420. In R.F. Barnes et al. (ed.) Forages: An introduction to grassland agriculture. 5th ed. Iowa State Univ. Press, Ames.

Nelson, C.J., and L.E. Moser. 1994. Plant factors affecting forage quality. p. 115-154. In G.C. Fahey, Jr. et al. (ed.) Forage quality, evaluation, and utilization. ASA, CSSA, and SSSA, Madison, WI.

Onstad, D.W., and G.W. Fick. 1983. Predicting crude protein, in vitro true digestibility, and leaf proportion in alfalfa herbage. Crop Sci. 23:961-964.

Perry, L.J., Jr., and D.D. Baltensperger. 1979. Leaf and stem yields and forage quality of three $\mathrm{N}$-fertilized warm-season grasses. Agron J. 71:355-358.

SAS Institute 1985. SAS user's guide: Statistics. 5th ed. SAS Inst., Cary, NC.

Van Soest, P.J. 1982. Nutritional ecology of the ruminant. O and B Books, Corvallis, OR. 